\title{
A Geophysical and Geologic Study of Nagata Seamount, Northern Line Islands*
}

\author{
W. W. Sager, G. T. Davis, B. H. Keating, and J. A. Philpotts \\ Hawaii Institute of Geophysics, University of Hawaii, \\ 2525 Correa Road, Honolulu, Hawaii, U.S.A.
}

(Received June 30, 1982)

\begin{abstract}
Nagata Seamount, located in the northern Line Islands at $12.5^{\circ} \mathrm{N}, 167.0^{\circ} \mathrm{W}$, was surveyed and dredged by the Hawaii Institute of Geophysics in the fall of 1979. The seamount is $3.7 \mathrm{~km}$ in height, approximately $45 \mathrm{~km}$ at maximum width, and has an estimated volume of $590 \mathrm{~km}^{3}$. Analysis of dredge rocks indicates that the seamount consists of alkali basalts and hyaloclastite breccias. Both acoustic reflection records and magnetic modeling studies indicate that the seamount is draped with a large volume of volcaniclastic debris about its base. At some time in its history Nagata Seamount may have been at or near sea level.

The bulk of the seamount is made up of lavas of normal magnetic polarity; however, the uppermost $1,000 \mathrm{~m}$ consists of reversely polarized rock. The virtual geomagnetic pole determined from the seamount falls at $61.6^{\circ} \mathrm{N}, 4.0^{\circ} \mathrm{E}$ not far from the average Cretaceous Pacific seamount pole. Rock magnetism studies of the dredged basalts indicate a stable magnetization. Three dimensional gravity modeling determined an average density of $2.5 \mathrm{~g} / \mathrm{cm}^{3}$ for the seamount. This value of the density agrees with other similar data from Pacific and Atlantic seamounts; although, unlike some other seamounts studied gravitationally, no large density variations were revealed on Nagata Seamount.

$\mathrm{K} / \mathrm{Ar}$ radiometric ages of $70 \mathrm{Ma}$ and $86 \mathrm{Ma}$ were obtained from the dredged basalts in agreement with the paleomagnetic pole. The younger age may result from alteration, thus the older date is considered more representative. This age is similar to that of nearby Kapsitotwa Seamount.
\end{abstract}

\section{Introduction}

During the fall of 1979 , three research cruises were undertaken with the Hawaii Institute of Geophysics research vessel KANA KEOKI to determine the origin and tectonic history of the Line Islands seamount chain. During these cruises, numerous previously unmapped bathymetric features were found, particularly in the southern portion of the chain. Acoustic, gravity, and magnetic surveys of selected seamounts and ridges were made along the chain, and dredge samples were collected for petrographic, radiometric, sedimentologic, and magnetic studies.

One of the seamounts selected for detailed geophysical study is located at $12.5^{\circ} \mathrm{N}$, $167.0^{\circ} \mathrm{W}$ (Fig. 1) in the northern half of the Line Islands seamount chain, on sea floor hypothesized to be $110 \mathrm{Ma}$ in age (WINTERER, 1976). This seamount has been given the

\footnotetext{
*Hawaii Institute of Geophysics, Contribution No. 1292.
} 


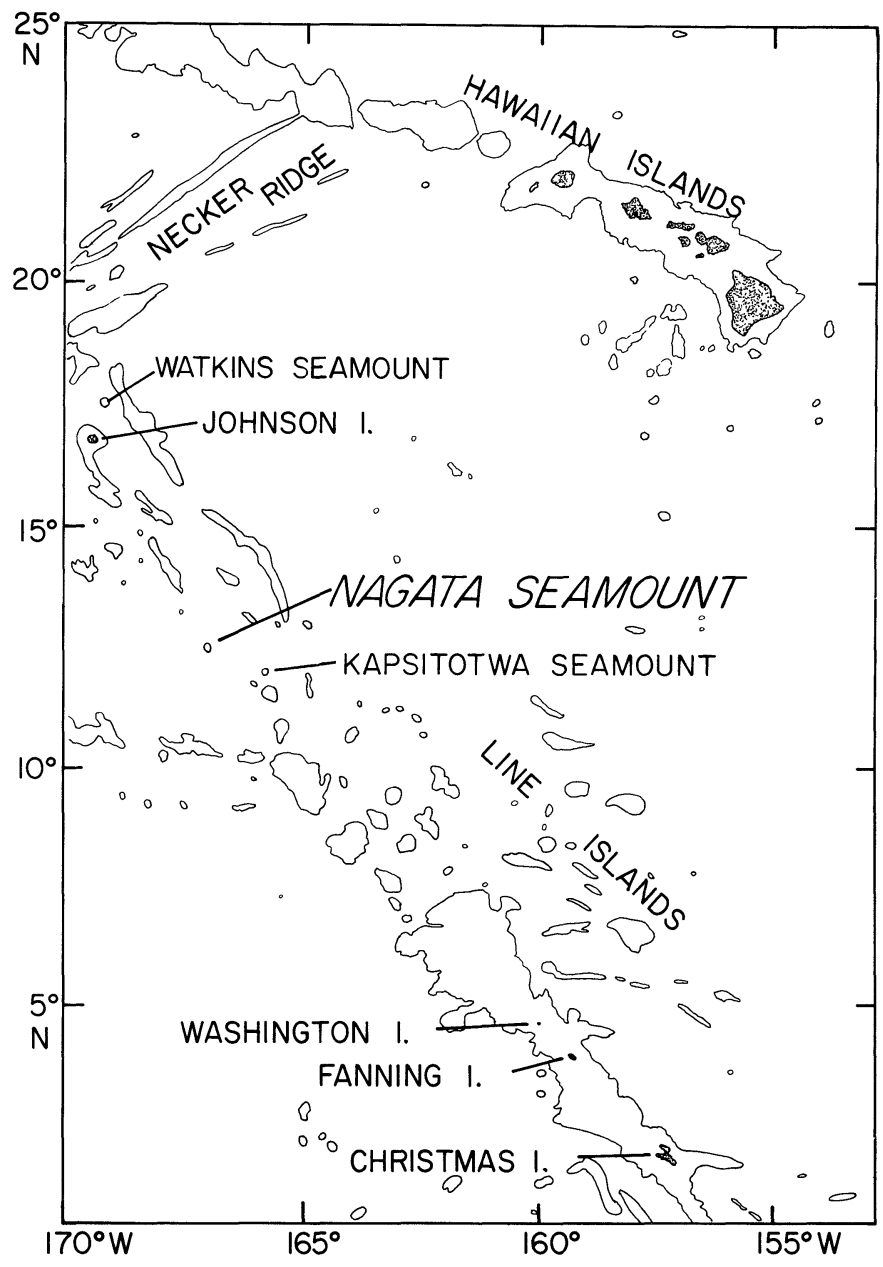

Fig. 1. Location map of Nagata Seamount. Solid lines are 0 and 2,000 fathom contours.

name 'Nagata Seamount' by principal investigators on the project, and official recognition has been requested from the U.S. Board on Geographic Names. This bathymetric feature is named for Takesi Nagata in recognition of his scholarly research in geomagnetism and his international leadership in geophysics, which has been an inspiration to his colleagues. Professor Nagata is one of the very few scientists whose work and contributions span the fields of rock magnetism, paleomagnetism, geomagnetism, and space magnetism. His pioneering studies in rock magnetism and classic text, Rock Magnetism (NAGATA, 1953) established the basis of this subject. Author of more than 300 scientific works, professor Nagata has been active in such science programs in Japan as the Japan Antarctic Expedition and the Japan Rocket Launching Facility. He was director of the Geophysical Institute and director of the National Institute for Polar Research, a past president of the International Association of Geomagnetism and Aeronomy, and a foreign member of the U.S. National Academy of Science. 


\section{Bathymetry}

The bathymetric contour map of Nagata Seamount is shown in Fig. 2. Ship tracks were positioned by Doppler satellite navigation. Ocean bottom depths were determined using conventional echo sounding techniques with a $3.5 \mathrm{kHz}$ source. The recorded acoustic travel times were corrected for the variation of sound waves in sea water (MATTHEws, 1939). Seismic reflection profiles were also recorded using an $80 \mathrm{in}^{3}\left(1,311 \mathrm{~cm}^{3}\right)$ airgun source. Line drawings from these seismic records are shown in Fig. 3.

Nagata Seamount rises $3,741 \mathrm{~m}$ from the ocean bottom to a minimum depth of $1,559 \mathrm{~m}$. The volcano is elongated in a north-south direction and has a maximum width of

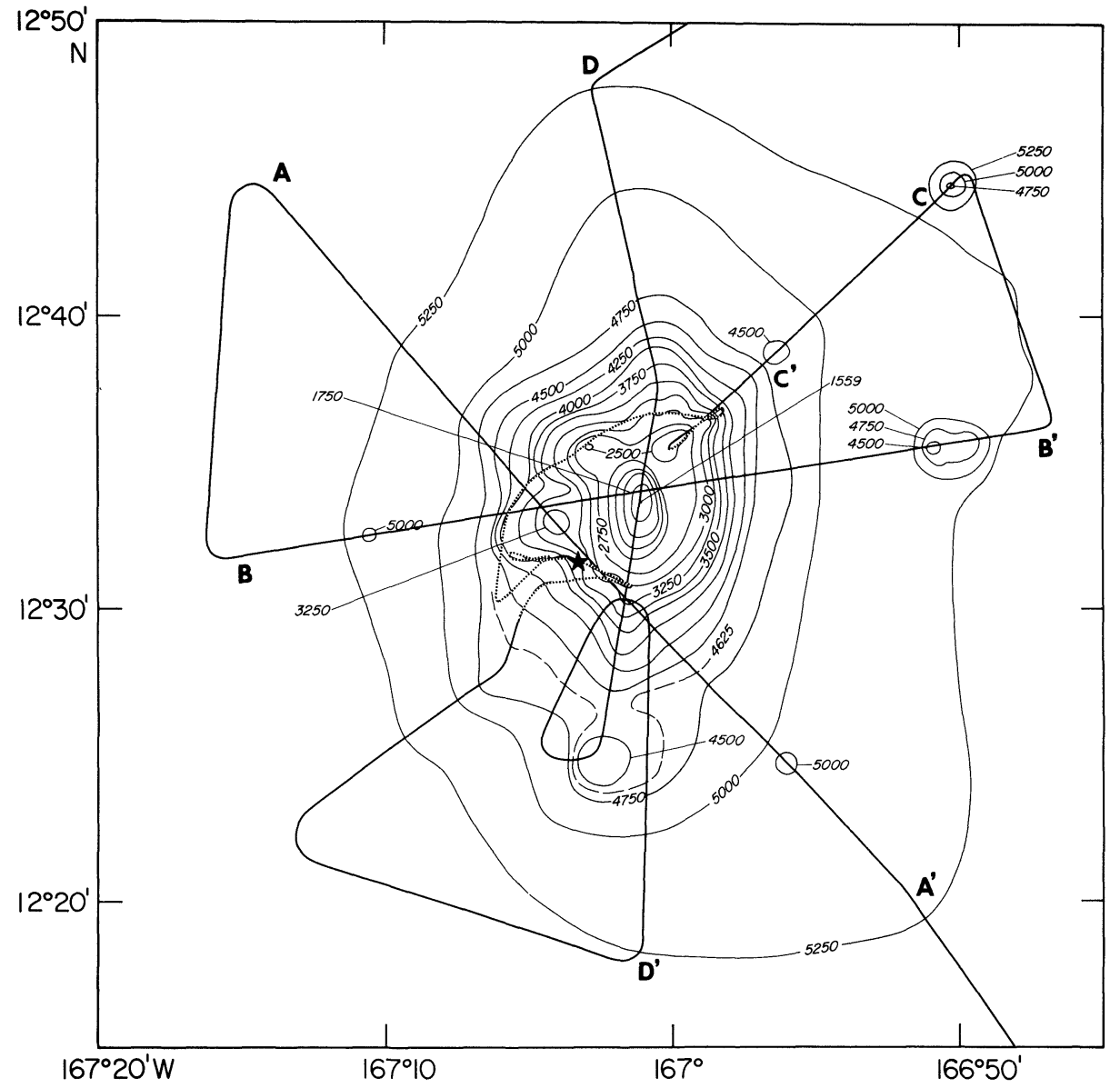

Fig. 2. Bathymetric contour map of Nagata Seamount. The light solid lines are depth contours with an interval of $250 \mathrm{~m}$, and dashed lines indicate supplementary $125 \mathrm{~m}$ contours. The heavy solid line corresponds to the ship track along which magnetic data recorded. The dotted line refers to the ship track unaccompanied by magnetic data. Capital letters correspond to the beginning and end points of the reflection records in Fig. 3. The star indicates the position of the dredge. 

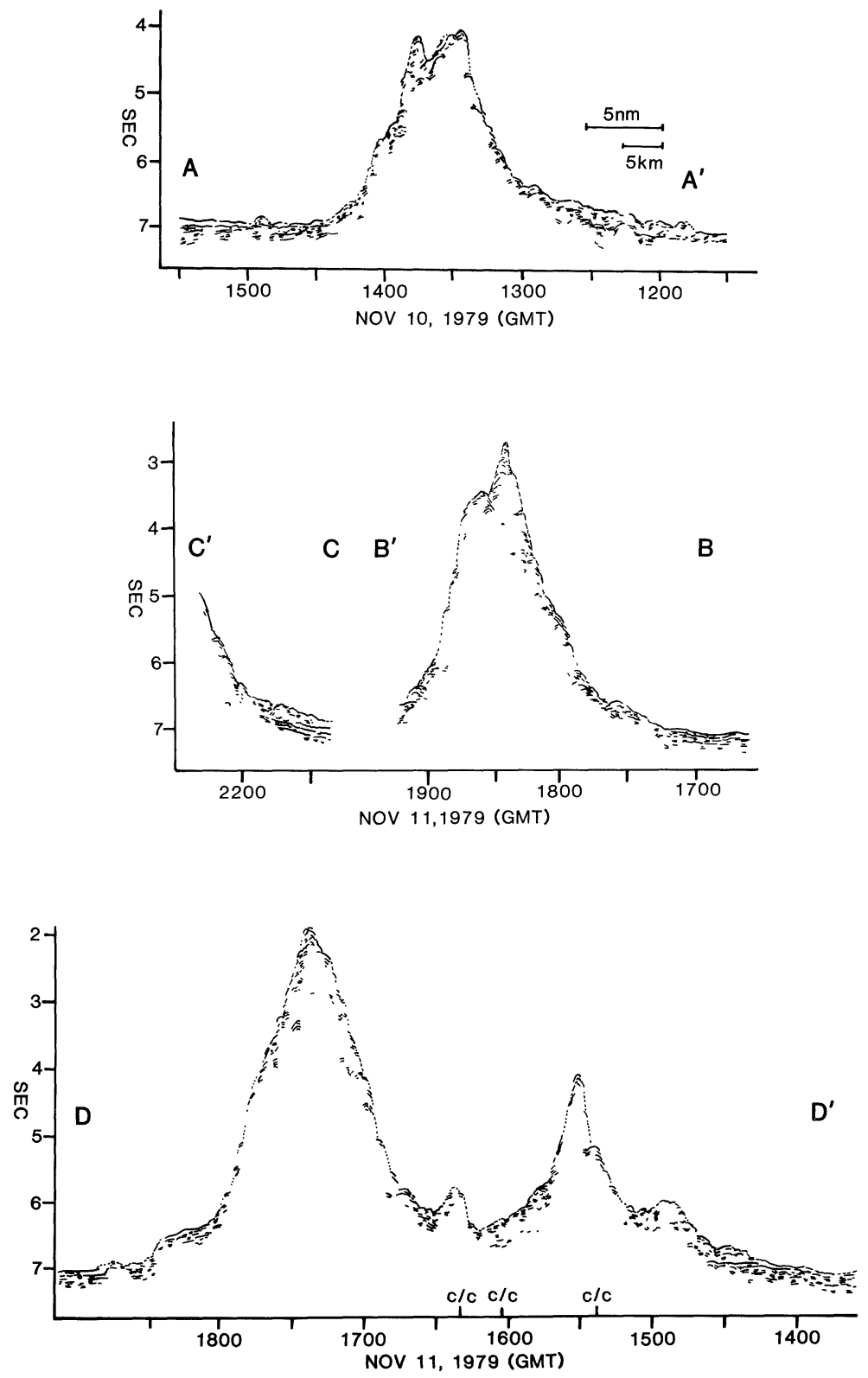

Fig. 3. Line drawings from acoustic reflection records of Nagata Seamount. Vertical scale is seconds of two way travel time. Horizontal scale is in hours (GMT). The vertical exaggeration is approximately 13:1. Capital letters refer to transects labelled in Fig. 2. Course changes are marked "c/c". 
$45 \mathrm{~km}$. Its flanks are steepest around the summit, averaging $25^{\circ}-30^{\circ}$, and least steep around the base where the slope decreases to approximately $4^{\circ}$. The volume of the seamount above the sea floor is approximately $590 \mathrm{~km}^{3}$.

Seismic reflection line B-B' in Fig. 3 shows a platform on the east side of the summit at about $3.5 \mathrm{sec}$ (two-way travel time). A hint of this feature is seen on line $\mathrm{D}-\mathrm{D}^{\prime}$ on the north face of the mountain at the same depth. The same terrace is seen on the depth sounder records obtained during the navigationally well-constrained dredge run to the north and west of the summit. We interpret these data as evidence for a platform at a depth of 2,500-2,750 $\mathrm{m}$ as shown in Fig. 2. The summit peak sits in the middle of this platform, and lobes protrude from the platform at $20^{\circ}, 260^{\circ}$, and $305^{\circ}$, clockwise from north as seen from the summit. Numerous small cones are observed around the base of the seamount; nearly every crossing of the volcano shows one or more. Three of these, at $45^{\circ}, 80^{\circ}$, and $185^{\circ}$ from the summit, are greater than $500 \mathrm{~m}$ in height.

\section{Seamount Paleomagnetism}

\subsection{The magnetic anomaly}

The magnetic residual anomaly (Fig. 4) displays the dipolar character of a normally polarized body consisting of rock magnetized with a moderate inclination in the southern hemisphere. The anomaly consists of a $300 \mathrm{nT}$ minimum over the top of the seamount, flanked by a $150 \mathrm{nT}$ maximum to the south and a smaller, relative high to the north.

The magnetic data were digitally recorded from a proton precession magnetometer towed $0.5 \mathrm{~km}$ behind the ship. The residual anomaly was obtained by subtracting the 1975 IGRF (International Geomagnetic Reference Field) from the measured total field and by making diurnal corrections. Diurnal corrections were derived from hourly average magnetic field data recorded at the U.S. Coast and Geodetic Survey's Honolulu Observatory (latitude $21^{\circ} 20^{\prime} \mathrm{N}$ ), which were scaled to latitude $12.5^{\circ} \mathrm{N}$ by using a curve of diurnal range versus latitude (ON wUMECHILLI, 1967). Induced currents in the ocean cause a phase shifting of the observed diurnal peak when the currents are deviated by an island (LINES and JONES, 1973). To remove this effect, the diurnal curve was shifted to peak at local noon.

\subsection{Technique}

Seamount paleomagnetism is an important tool for examining the motion of the Pacific plate, particularly in those areas formed during the Cretaceous quiet interval where there are few magnetic lineations. VACQUIER (1962) first suggested that the average intensity and direction of the magnetization vector of a seamount might be calculated by comparing magnetic and bathymetric surveys. The bathymetry is used to approximate the seamount shape with geometric bodies whose magnetic fields can be easily calculated. A linear least squares inversion of the observed magnetic anomaly is performed using the bathymetric model to constrain the direction and intensity of the magnetization vector of the seamount. The direction of magnetization can then be used to calculate a virtual geomagnetic pole for the seamount.

\subsection{Nagata Seamount model}

In Fig. 5 we show the bathymetric model used to calculate the best fitting magnetic 


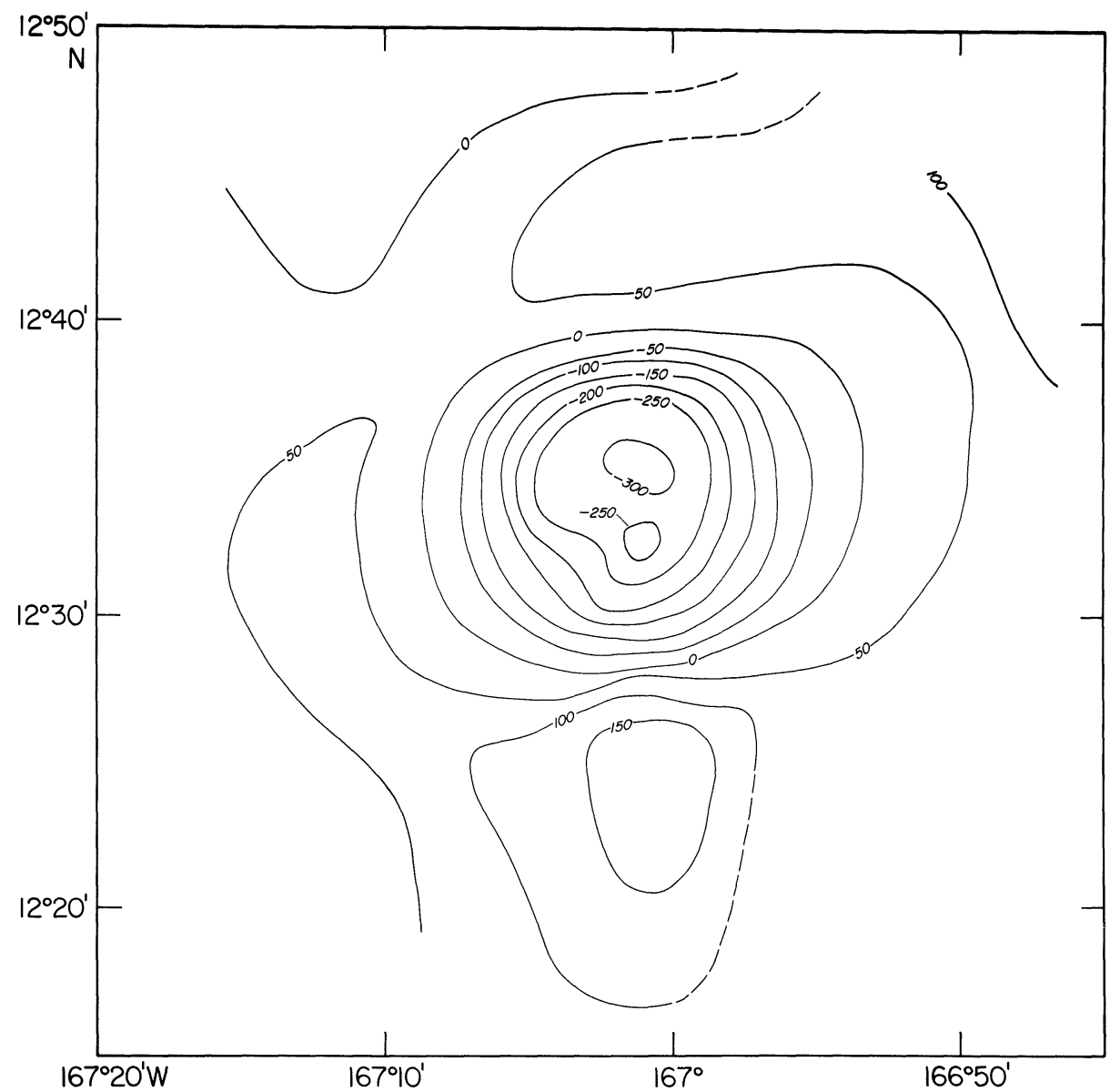

Fig. 4. Magnetic anomaly of Nagata Seamount. The anomaly is the total field residual (observed minus 1975 IGRF) corrected for diurnal variations. The contour interval is $50 \mathrm{nT}$.

anomaly. The upper surfaces of the prisms are polygons drawn to approximate the depth contours in Fig. 3. The magnetic field of the prisms are calculated (PlOUfF, 1976) and summed to approximate the magnetic anomaly of the seamount. The calculated anomaly is shown in Fig. 6a and the residual field (observed minus calculated) in Fig. 6b.

A number of different models were tested for the seamount; their parameters are listed in Table 1. In all of these models, the induced magnetic field was assumed to be negligible compared to the magnetic field caused by the remanent magnetism. Our studies of the magnetic properties of basalts dredged from Nagata Seamount imply that this assumption may not be entirely valid since the $Q n$ is approximately 7; however, our success with the magnetic modeling indicates that the effect of the remanent magnetization is much larger than the effect of the induced magnetization.

The initial models approximated the bathymetry shown in Fig. 2 with the addition of a $250 \mathrm{~m}$ extension of the seamount below the sediments as indicated by the seismic reflection records shown in Fig. 2. The resulting calculated anomaly was of shorter wavelength than 


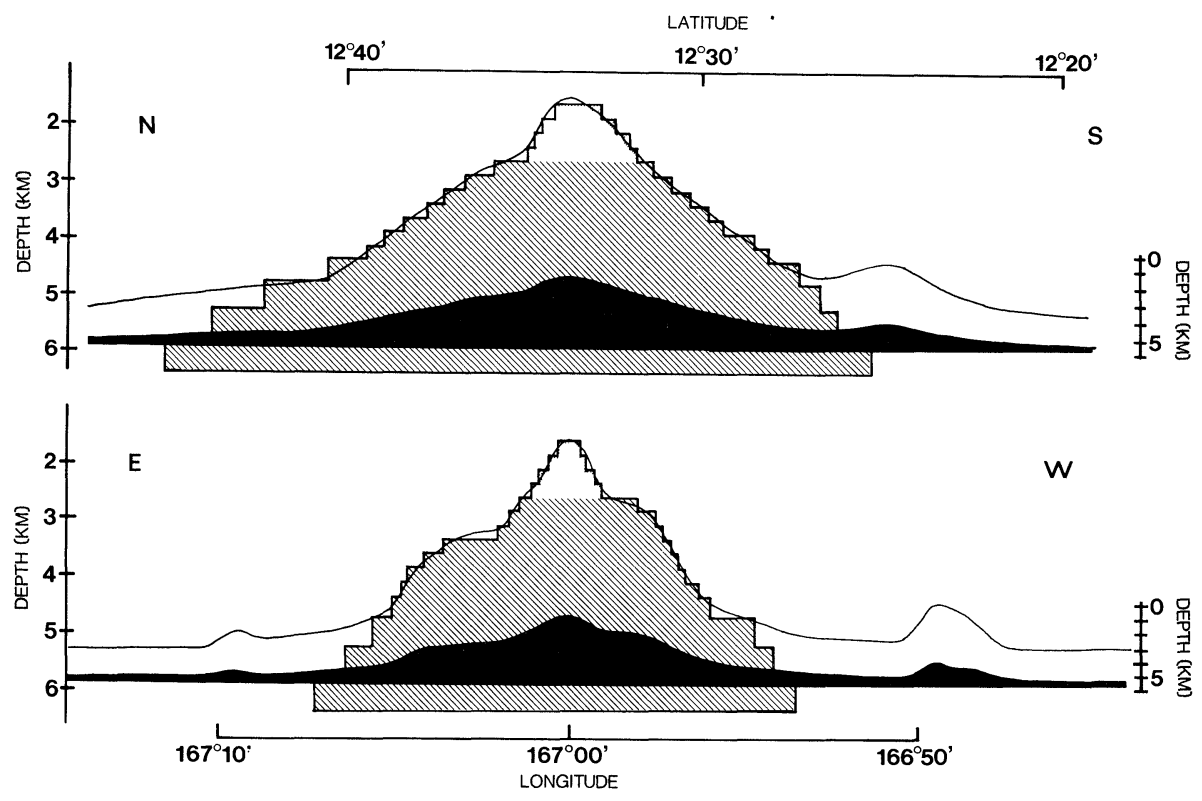

Fig. 5. Bathymetric and magnetic models. In this figure two perpendicular cross sections of the seamount are shown. The vertical scale is in thousands of meters and the horizontal scale is degrees of latitude or longitude. The silhouette shows a cross section of the seamount with no vertical exageration, and the solid line is a $3: 1$ vertical exageration of the bathymetry. The jagged line represents the edges of the prisms used to approximate the bathymetry for the magnetic model. The hachured portion of the model is normally polarized and the unhachured summit is reversely polarized.

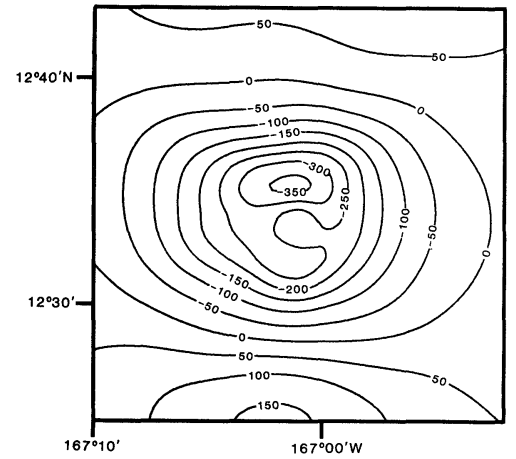

a

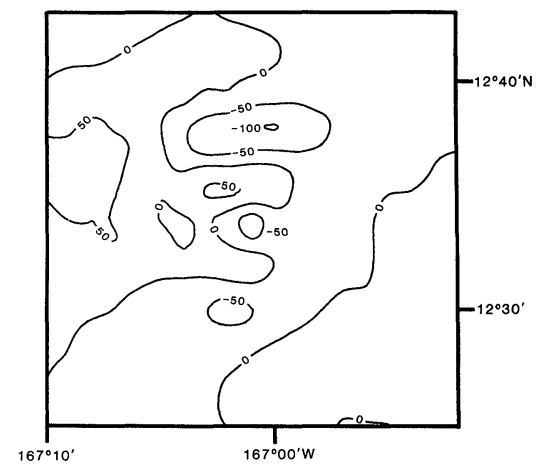

b

Fig. 6. Calculated and residual magnetic anomalies. The map on the left is the magnetic anomaly calculated from the bathymetric model using the magnetization parameters in model $\mathrm{D}$ of Table 1. The map on the right shows the residual anomaly (observed minus calculated). Contours are at $50 \mathrm{nT}$ intervals. 
Table 1. Magnetization model parameters.

\begin{tabular}{|c|c|c|c|c|c|c|c|c|c|c|c|c|}
\hline \multirow{2}{*}{ Model } & \multirow{2}{*}{ Top } & \multirow{2}{*}{ Bottom } & \multirow{2}{*}{$\begin{array}{c}\text { Inc. } \\
\left({ }^{\circ} \text { Down }\right)\end{array}$} & \multirow{2}{*}{$\begin{array}{l}\text { Dec. } \\
\left({ }^{\circ} \mathrm{E}\right)\end{array}$} & \multirow{2}{*}{$\begin{array}{l}\text { Int. }{ }^{(a)} \\
(\mathrm{A} / \mathrm{m})\end{array}$} & \multicolumn{3}{|c|}{ Planar regional } & \multirow{2}{*}{$r^{(\mathbf{b})}$} & \multirow{2}{*}{$R^{(\mathrm{c})}$} & \multirow{2}{*}{$\begin{array}{l}\text { Lat. } \\
\left({ }^{\circ} \mathrm{N}\right)\end{array}$} & \multirow{2}{*}{$\begin{array}{c}\text { Long. } \\
\left({ }^{\circ} \mathrm{E}\right)\end{array}$} \\
\hline & & & & & & $C_{0}$ & $C_{1}$ & $C_{2}$ & & & & \\
\hline$A^{(1)}$ & 2625 & 6350 & -19.0 & 6.0 & 4.97 & 90.0 & 0.0 & 0.0 & 2.0 & 0.91 & 67.0 & 357.8 \\
\hline $\mathrm{B}^{(2)}$ & 1600 & 6350 & -22.6 & 2.9 & 3.92 & 44.0 & 0.0 & 0.0 & 3.7 & 0.97 & 65.6 & 6.1 \\
\hline$C^{(2)}$ & 1600 & 6350 & -26.0 & 1.3 & 3.85 & 106.0 & -1.12 & -0.62 & 3.9 & 0.97 & 63.7 & 10.1 \\
\hline$D^{(2)}$ & 1600 & 6350 & -29.0 & 4.4 & 3.76 & 10.8 & -2.05 & 0.36 & 3.7 & 0.96 & 61.6 & 4.0 \\
\hline \multirow[t]{2}{*}{$E^{(3)}$} & 1600 & 2625 & 22.6 & 182.9 & 3.69 & 44.0 & 0.00 & 0.00 & 3.7 & 0.97 & 65.6 & 6.1 \\
\hline & 2625 & 6350 & -22.6 & 3.9 & 3.91 & 44.0 & 0.00 & 0.00 & 3.7 & 0.97 & 65.6 & 6.1 \\
\hline
\end{tabular}

\footnotetext{
${ }^{(1)}$ Upper 1,000 $\mathrm{m}$ removed, bottom extended 1,100 $\mathrm{m}$ below ocean floor.

${ }^{(2)}$ Smaller area of base, top $1,000 \mathrm{~m}$ reverse polarity.

${ }^{(3)}$ Magnetization direction from $\mathrm{B}$, intensity of magnetization of top and bottom allowed to be different. (a) $1 \mathrm{~A} / \mathrm{m}=10^{-3} \mathrm{emu} / \mathrm{cc}$.

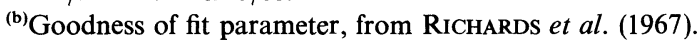

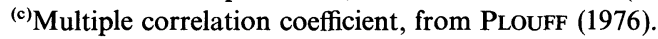

the observed anomaly; consequently, we extended the bottom of the seamount farther below the ocean floor and removed the uppermost layers as has been done with other Pacific seamounts (RICHARDS et al., 1967; HARRISON, 1971; HARRISON et al., 1975). The best fitting-model (A, Table 1) had its bottom at a depth of $6,350 \mathrm{~m}$ and its top at 2,625 m, i.e. a removal of the top $1,066 \mathrm{~m}$ and an extension of the bottom by $1,100 \mathrm{~m}$. Although the goodness of fit parameter, $r$ (RICHARDS et al., 1967) and the multiple correlation coefficient, $R$ (PloufF, 1976) were sensitive to the amount of material assumed non-magnetic on the top, these parameters were not as sensitive to changes in the depth to the bottom.

Two discrepancies between the calculated and observed anomalies led us to reconsider this model. First, the magnetic anomaly calculated from model A is elongated east-west much more than the observed anomaly (aspect ratio of the $0 \mathrm{nT}$ contour: observed, 1.14; calculated, 1.90). Second, the area of the minimum observed anomaly in Fig. 4 is not as smooth as predicted. Instead, the observed minimum is slightly north of the peak and there is a relative maximum just south of the peak. This observation suggests that the upper portion of the peak is magnetized with reversed polarity pushing the minimum of the anomaly north of the peak.

The east-west elongation of the anomaly calculated from Model A is due, in part, to the large base given that model. From the bathymetry in Fig. 2, it is seen that, above $4,750 \mathrm{~m}$, the seamount is elongated in a north-south direction. Below $4,750 \mathrm{~m}$, the slope of the seamount decreases greatly. The base defined by the $5,250 \mathrm{~m}$ contour is broad and not as elongated as the upper parts of the seamount. We tested a number of models with various sub-sediment configurations. The best configuration was chosen as the model that produced the highest value of $r$ and $R$. This configuration was then used in subsequent models B, C, D, E and is shown in Fig. 5. It has some interesting geological implications. As seen in Fig. 5, the sub-sediment prisms keep the same slope as the upper part of the seamount and do not follow the low angle apron that extends from the seamount's base. The secondary cone on the south flank is assumed non-magnetic and thus some of the southern extension of the seamount is cut off, as is seen in Fig. 5. The resulting model of Nagata Seamount suggests that the seamount flanks are buried in non-magnetic material, 
probably hyaloclastite, a result supported by the seismic reflection records in Fig. 2. We believe that the non-magnetic material is hyaloclastite because a large amount of such material was dredged from the seamount.

In order to approximate the reversely magnetized peak, the upper 1,000 m, which had been removed previously, was given a magnetization vector of the same magnitude, but opposite direction, as that of the bulk of the seamount. Models B, C, and D (Table 1) use this configuration of the model, but differ in their assumption of the regional field to be removed from the observed data. Model $\mathrm{E}$ uses the same direction of magnetization as determined in model $\mathrm{B}$ but allows the intensities of the magnetization vectors of the top and bottom to be least squares adjusted to maximize the goodness-of-fit parameter. Entry E of Table 1 shows that the assumption that the intensity of magnetization of the top and bottom are equal is not far from being correct. The magnetizations for the top and bottom were calculated to be $3.69 \mathrm{~A} / \mathrm{m}$ and $3.91 \mathrm{~A} / \mathrm{m}$, respectively. These intensities, particularly that of the top, are dependent on the placement of the assumed division between lavas of reverse and normal polarity. The decision to make the top four prisms in Fig. 5 of reverse polarity was based upon our observation of the platform $1,000 \mathrm{~m}$ below the peak. The platform may represent a hiatus in the building of the edifice. Thus, if this hiatus marks a significant erosional or structural horizon, it is a logical place to assign a polarity boundary. Also, this platform has a much greater areal extent than the summit peak. If prisms below $2,500 \mathrm{~m}$ are assumed to be of reverse polarity, the effect on the calculated anomaly is much greater than is indicated by the observed anomaly in Fig. 4.

\subsection{Removal of the regional field}

Models B, C, D in Table 1 differ by the manner in which each accounts for the regional magnetic anomaly. Most authors invert the anomaly to obtain three magnetization parameters and three regional field parameters. The equation for the calculated magnetic anomaly, $T_{i}$, at observation point $i$ is

$$
T_{i}=J l B_{i 1}+J m B_{i 2}+J n B_{i 3}+R_{i}
$$

where $J l, J m, J n$ are the three components of the magnetization vector, the $B_{i j}(j=1,2,3)$ are volume integrals of the magnetized bodies, and $R_{i}$ is the regional field. In Model B, Eq. (1) was used with $R_{i}$ being a constant offset determined in the least squares routine,

$$
T_{i}=J l B_{i 1}+J m B_{i 2}+J n B_{i 3}+C_{0} .
$$

When $R_{i}$ is assumed to be a planar regional, as in model C, Eq. (1) becomes

$$
T_{i}=J l B_{i 1}+J m B_{i 2}+J n B_{i 3}+C_{0}+C_{1} X+C_{2} Y
$$

with $X, Y$ being cartesian coordinates corresponding to north and east. This is the formulation used by most authors. Another approach to the regional removal was used on model D. A least squares regional plane was removed from the observed anomaly before it was input to the program and three magnetization parameters and an offset were determined as in Eq. (2).

From comparison of the planar regionals calculated in models $\mathrm{C}$ and $\mathrm{D}$, it appears the 
largest contribution is north-south, coincident with the direction of the magnetization vector. The plane determined simultaneously with the magnetization parameters (model C) has half the north-south slope of the plane determined separately, and it dips to the east while the other dips to the west. We note that in the magnetic anomaly map in Fig. 4, values are larger in the southeast corner and smaller in the northwest corner. This observation is concordant with the least squares plane determined separately in model D.

The magnetization parameters derived from each of these models give virtual poles that differ by only a few degrees. The greatest distance between any two of these poles is $6^{\circ}$ (between A and D, see Fig. 7). There has been some debate in the literature about which of these three methods is the proper way to remove the regional. For most seamounts with large anomalies, the derivation of a regional plane with the magnetization parameters appears to change the virtual geomagnetic pole by a few degrees at most; however, seamounts with small anomalies may have their virtual poles moved much larger distances. Our studies of central Pacific seamounts suggest that one must not blindly accept a direction of magnetization derived simultaneously with a regional field, particularly if the regional accounts for more than $15-20 \%$ of the anomaly. In our calculations, the planar regionals in Models $\mathrm{C}$ and $\mathrm{D}$ amount to only $7 \%$ and $10 \%$ of the anomaly, respectively. As we have good lateral sampling of the magnetic anomaly and there seems to be a slight spurious regional field, we accept model $D$, the one which seems to satisfactorily approximate the regional, as the best model.

The virtual poles from the models in Table 1 are plotted in Fig. 7 with poles from other Cretaceous seamounts (HARRISON et al., 1975). The poles from Nagata Seamount all lie in

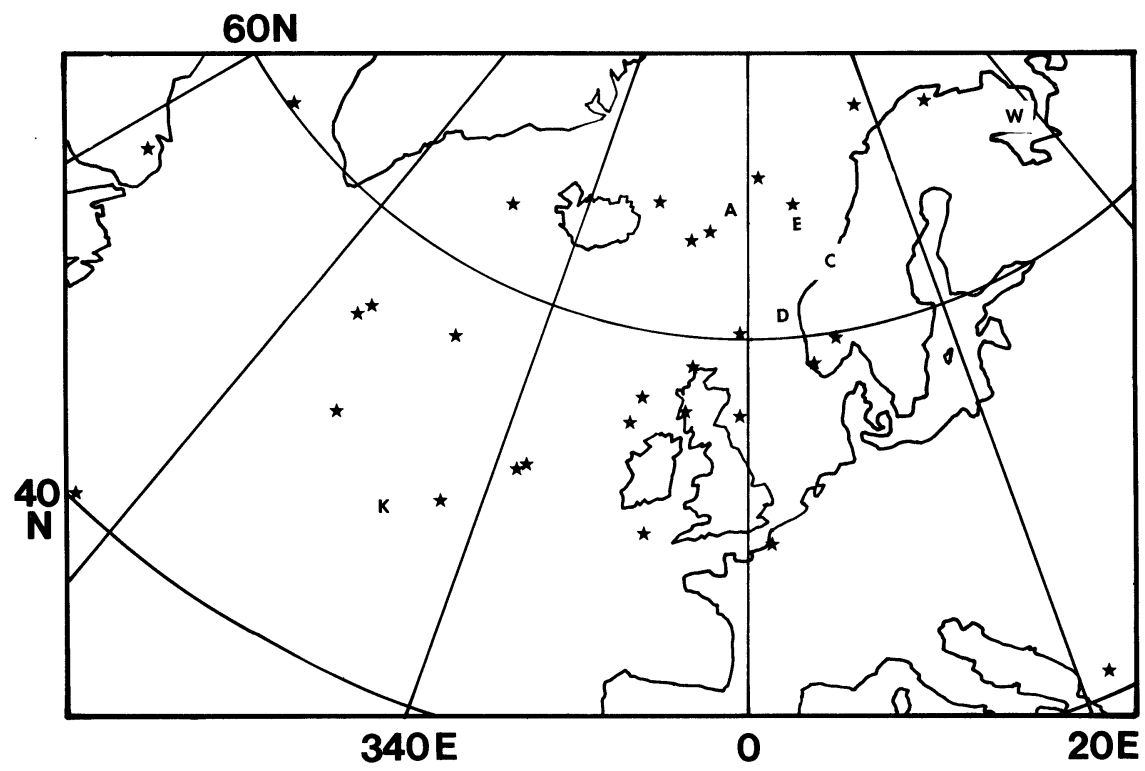

Fig. 7. Virtual geomagnetic poles (VGP's). The stars correspond to VGP's of Cretaceous seamounts from HARRISON et al. (1975). K and W refer to VGP's of Kapsitotwa and Watkins Seamounts. The letters A, C, D, E show the positions of the VGP's of the models listed in Table 1. Models B and E, from Table 1 have the same VGP. 
the central to northeastern area of that distribution of Cretaceous poles, a result that agrees with other evidence of seamount's Late Cretaceous age. Two other seamount poles have been calculated from seamounts in the Line Islands chain. Nearby Kapsitotwa Seamount has a pole at $47.5^{\circ} \mathrm{N}, 333.5^{\circ} \mathrm{E}$ (HARrison et al., 1975) and is $84 \mathrm{Ma}$ (SAITo and OzIMA, 1977), while Watkins Seamount, of undetermined age, has a VGP at $68.3^{\circ} \mathrm{N}, 38.7^{\circ} \mathrm{E}$ (KEATING and SAGER, 1980). GoRdON and Cox (1980) have determined an average Pacific paleomagnetic pole for $82 \mathrm{Ma}$ that falls at $56.5^{\circ} \mathrm{N}, 353.5^{\circ} \mathrm{E}$ with an $\alpha_{95}$ of $5^{\circ}$. This is close to the Nagata pole of $61.6^{\circ} \mathrm{N}, 4.0^{\circ} \mathrm{E}$.

\section{Magnetic Properties of Dredged Basalts}

Samples for magnetic property studies were collected by drilling one inch diameter cylinders into the unoriented dredged rocks. These cylinders were then given orientations and cut into one inch long specimens. The specimens were measured on a Schonstedt spinner magnetometer within the doubly shielded $\mu$-metal room (field 50-200 nT) at the Hawaii Institute of Geophysics.

Our results suggest that the majority of the samples collected from the dredge on Nagata Seamount are stably magnetized. All of the measured samples displayed only minor changes in the direction of magnetization when subjected to alternating field demagnetization (see Fig. 8a). These samples were progressively demagnetized in alternating fields up to $600 \mathrm{Oe}$. The mean destructive field was found to be more than $400 \mathrm{Oe}$.

The mean intensity of magnetization of the samples was found to be $3.9 \mathrm{~A} / \mathrm{m}$, about the same value as determined from the seamount anomaly study described above. The mean volume susceptibility was measured to be $2.14 \times 10^{-2}$ SI $\left(1.70 \times 10^{-3} \mathrm{emu}\right)$ which gives a Koenigsberger ratio, Qn, of 6.9 (assuming a magnetic field strength of 33,390 nT).

Numerous Curie temperature analyses were conducted on samples from Nagata Seamount (see Fig. 8c and d) and other Line Island edifices. The Curie temperatures ranged from $555^{\circ} \mathrm{C}$ to $434^{\circ} \mathrm{C}$ as shown in Fig. 9. The mean Curie temperature was $495^{\circ} \mathrm{C}$, which suggests that the magnetic material in these rocks is titanomagnetite displaying various degrees of oxidation. Microscopic examination shows titanomagnetite indeed is present as phenocrysts and in the groundmass. The titanomagnetite displays a trellis exsolution pattern.

\section{Gravity}

The gravity data were collected using a LaCoste-Romberg stable platform gravimeter. These values were recorded at $5 \mathrm{~min}$ intervals along the ship track and tied to the international gravity base network of WoOLLARD and Rose (1963). The data were reduced to free-air anomalies with respect to the international reference ellipsoid (GARLAND, 1965; HEISKANEN and MORITZ, 1967) with a flattening of $1 / 297.0$. The mean crossing error of the survey is approximately $5 \mathrm{mGal}$.

A contour map of the free-air anomaly over the seamount is shown in Fig. 10. The anomaly follows the bathymetry, as expected. It is elongated north to south with a maximum of $87 \mathrm{mGal}$ over the peak.

The same vertical-sided polygonal prisms used in the magnetic model were used to 


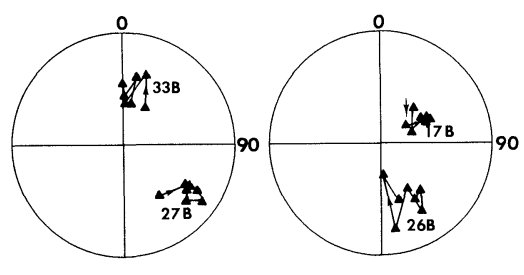

a

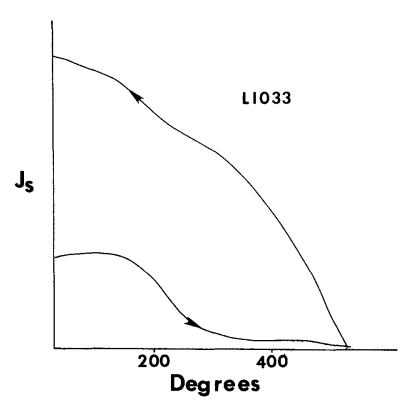

c

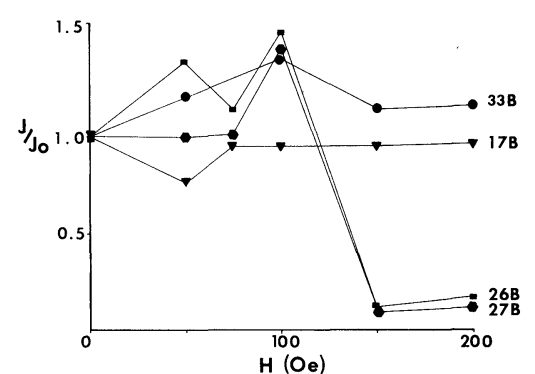

b

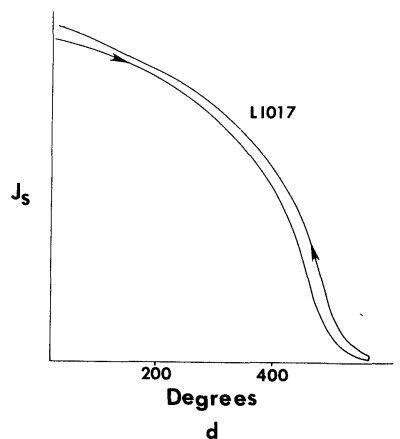

Fig. 8. (a) Stereographic projection of the directions of magnetization upon progressive alternating field demagnetization for samples from the Line Islands. All samples have positive inclinations. Two symbols were used for clarity where sample directions overlap. Sample numbers are given in bold print. Samples 17 and 26 are from Nagata Seamount.

(b) Normalized plot of the change in sample direction upon alternating field demagnetization. The normalized sample intensity is plotted along the vertical axis, and the alternating field applied is plotted along the horizontal axis.

(c) and (d) Comparison of thermomagnetic curves for typical samples from the Line Islands seamounts. Sample LI-033 (c) is a thermally irreversible type whereas sample LI-017 (d) is nearly reversible. The intensity of the magnetization is plotted on the vertical scale and the temperature in degrees Celcius is plotted on the horizontal scale. The arrows designate heating and cooling curves.

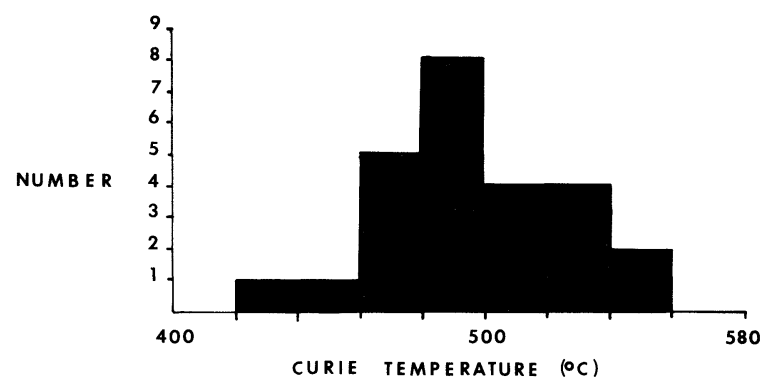

Fig. 9. Distribution of Curie temperatures for rocks dredged in the Line Islands. The samples from Nagata Seamount fall near the center of the histogram. 


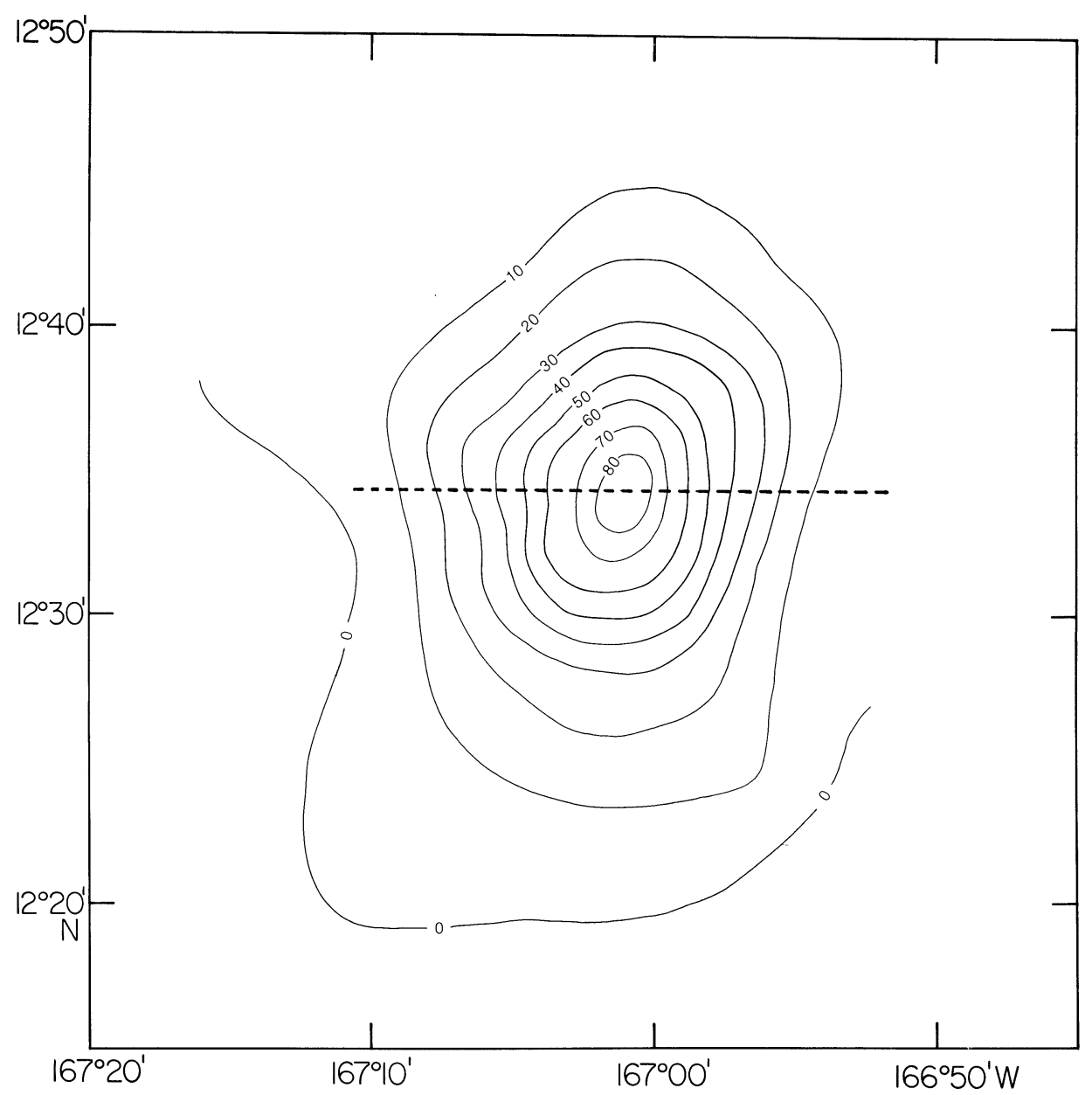

Fig. 10. Free air anomaly of Nagata Seamount. Contours are at 10 milligal intervals. The dashed line corresponds to the transect shown in Fig. 11.

approximate the seamount shape. The gravity anomalies of these prisms were calculated (PLOUF, 1976) and used in a linear least squares inversion of the observed gravity anomaly to determine the average density of the seamount. The entire seamount, from the summit down to the approximate sea bottom at $5,250 \mathrm{~m}$, was assumed to be of one homogeneous density.

A density of $2.48 \mathrm{~g} / \mathrm{cm}^{3}$ (standard deviation $0.02 \mathrm{~g} / \mathrm{cm}^{3}$ ) was determined from this model. This value compares well with densities of $2.5 \mathrm{~g} / \mathrm{cm}^{3}$ for Chatauqua Seamount (SCHIMkE and Bufe, 1968) as well as $2.6 \mathrm{~g} / \mathrm{cm}^{3}$ for an unnamed Atlantic seamount (LePichon and TAlwani, 1964). This value is somewhat higher than the density of $2.3 \mathrm{~g} / \mathrm{cm}^{3}$ found for Oahu (Woollard, 1951) and Jasper Seamount (HaRrison and BRISBIN, 1959); however, it should be noted that these studies were done with two dimensional methods which would tend to overestimate the volume of a seamount and thus under-estimate its density. 
The value of the density represents an average for the whole of the seamount. The upper surfaces of most seamounts consist of breccias and vesicular basalts of densities as low as $2.0 \mathrm{~g} / \mathrm{cm}^{3}$ (NAYUdu, 1962; LePICHON and TAL WANI, 1964 ; STRANGE et al., 1965). On the other hand, the interiors of most seamounts are probably made up of denser rock up to 2.9-3.0 g/cm ${ }^{3}$ (STRANGE et al., 1965; ROBERTSON, 1967, 1970). Thus our average estimate is not unreasonable. Figure 11 shows a west to east transect passing over the summit, through the calculated and observed anomalies. It is seen that the maximum difference between the observed and calculated anomalies is $3 \mathrm{mGal}$, well within the survey error. This model is simpler than expected from geological considerations and it is non-unique, as are all such gravity models. Figure 11 is representative of the overall fit of the observed and calculated gravity anomaly, and it shows that the model has adequately explained the observed gravity anomaly. A "goodness of fit" parameter value of 6.5 was obtained from this model, indicating that it accounts for $86 \%$ of the observed anomaly.

\section{Petrology and Geochemistry}

A single dredge on the southern flank of Nagata Seamount (Hawaii Institute of Geophysics, RD-059) recovered a diverse suite of volcanic rocks and volcanoclastic breccias. The dredge site, located at $12^{\circ} 31.0^{\prime} \mathrm{N}, 167^{\circ} 03.3^{\prime} \mathrm{W}$, lies approximately $4.5 \mathrm{~km}$ southwest of the summit at a water depth of 3,200-3,400 m. Whole rock major, trace and rare-earth element analyses of two basalt types are reported along with three $\mathrm{K} / \mathrm{Ar}$ ages. Analyses of this and other HIG dredges from the Line Islands were reported by DAVIS (1982).

\subsection{Volcanic rock petrography}

The volcanic rocks may be separated into two groups on the basis of petrography:

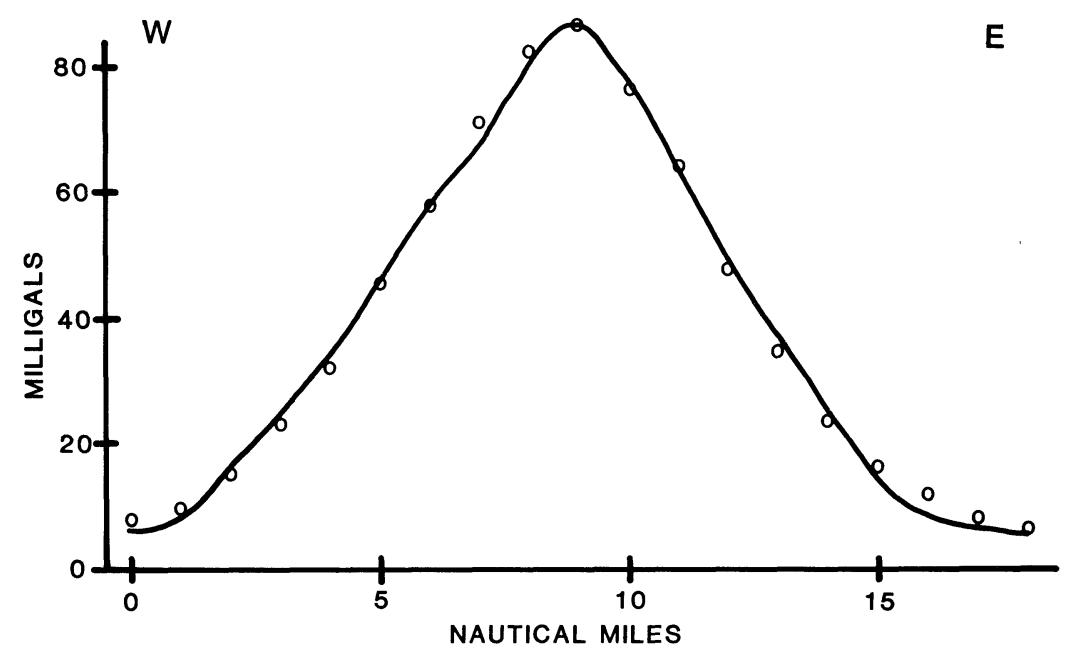

Fig. 11. Comparison of observed and calculated gravity anomalies. The solid line corresponds to the observed free air anomaly while the open circles are values calculated from the bathymetric model. The transect runs from west to east across the summit. 
vesicular alkali olivine basalts and massive amphibole-phyric alkali basalts. The alkalic olivine basalts are nearly all olivine-phyric, up to $15 \%$ by mode, with lesser amounts of titaniferous augite and plagioclase as phenocrysts. The euhedral to subhedral olivines, typically less than $4 \mathrm{~mm}$ long, are completely replaced by reddish-brown iddingsite in all samples. The augites are nearly all fractured, rounded, and partially resorbed. Plagioclase occurs as tabular to square crystals and fragments, commonly zoned, with some displaying reaction rims. Altered glass mesostasis, forming up to $20 \%$ of the rock, is replaced by brownish-gray smectite-group clay minerals. Calcite and alkali feldspar appear in trace amounts and are probably of secondary origin. Groundmass phases include replaced olivine microphenocrysts and fragments, clinopyroxene and plagioclase chips and laths, clots of magnetite, and fine-grained titanomagnetite needles, displaying trelliced exsolution patterns. Textures vary from porphyritic to hypocrystalline. The presence of titaniferous augite and groundmass olivine have been used by MACDONALD and KATSURA (1964) as a petrographic indicator of the alkalic nature of the rock. Vesicles in these basalts are round, less than $6 \mathrm{~mm}$ in diameter, up to $35 \%$ by mode, and may be lined or infilled with clays, carbonate, or both.

The amphibole-phyric alkali basalts contain $0-15 \%$ titaniferous amphiboles, typically less than $3 \mathrm{~mm}$ long and commonly zoned, and rare titaniferous augite phenocrysts set in a subtrachytic matrix of aligned plagioclase laths, magnetite clots, titanomagnetite needles, and minor amounts of amphibole and pseudomorphs after olivine. Trace microcrystalline apatite needles are present in a few samples. The altered glass mesostasis of these basalts, up to $15 \%$ by mode, is similar to that of the alkali olivine basalts, but may also contain trace zeolites (natrolite and phillipsite). The vesicles present, less than $10 \%$ by mode, are elongated and flattened; up to $3 \mathrm{~cm}$ long but less than $3 \mathrm{~mm}$ thick, they are aligned parallel to the groundmass texture and are commonly thinly lined with carbonate.

Two types of xenoliths are present, one in each basalt type. The alkali olivine basalts contain rare medium-grained aggregates of replaced olivine and clinopyroxene, generally less than $1.0 \mathrm{~cm}$ in diameter. The amphibole-phyric alkali basalts contain rare xenoliths of clinopyroxene and spinels poikilitically enclosed by titaniferous amphibole. These xenoliths are generally $1-2 \mathrm{~cm}$ in diameter with finer biotite flakes on their perimeters. Neither xenolith type contains aluminous orthopyroxene or garnet, which are present in xenoliths of undersaturated Hawaiian lavas. The lack of these high pressure phases suggests an origin in an environment with pressure less than $20 \mathrm{~Kb}$ (LAMBERT and WYLLIE, 1970).

\subsection{Geochemistry}

A representative basalt from each of the two petrographic types was selected for geochemical analyses: sample 59-1 for the alkali olivine basalts and sample 59-7 for the amphibole-phyric alkali basalts. These samples were crushed and sieved to $2 \mathrm{~mm}$ diameter chips to remove replaced olivine phenocrysts, xenolithic material, and vesicle linings, then ultrasonically cleaned in deionized-distilled water, and oven dried at $80^{\circ} \mathrm{C}$ for $4 \mathrm{hr}$ before final crushing to a fine powder in a boron carbide grinder. Major and selected trace element analyses were performed by X-ray fluorescence and atomic absorption spectrophotometry. These results, adjusted anhydrous analyses and C.I.P.W. norms are presented in Table 2 and petrographic modes for 59-1 and 59-7 appear in Table 3. Rare-earth and additional trace element analyses were performed by isotope dilution mass spectrometry at the University of Hawaii. The results and chondrite-normalized values appear in Table 4. 
Table 2. Adjusted anhydrous trace element analyses and C.I.P.W. norms.

\begin{tabular}{|c|c|c|c|c|c|c|c|c|}
\hline & \multicolumn{2}{|c|}{$59-1$} & \multicolumn{2}{|c|}{$59-7$} & \multicolumn{4}{|c|}{ CIPW norms } \\
\hline & A & B & A & B & & & $59-1$ & $59-7$ \\
\hline $\mathrm{SiO}_{2}$ & 47.30 & 49.98 & 50.25 & 52.29 & & $\mathrm{C}$ & 0.6 & \\
\hline $\mathrm{Al}_{2} \mathrm{O}_{3}$ & 16.57 & 17.51 & 17.72 & 18.43 & & OR & 19.9 & 22.4 \\
\hline $\mathrm{Fe}_{2} \mathrm{O}_{3}$ & 11.63 & 2.08 & 4.19 & 1.08 & & $\mathrm{AB}$ & 28.3 & 37.2 \\
\hline $\mathrm{FeO}$ & 1.52 & 11.82 & 2.76 & 6.15 & & $\mathrm{AN}$ & 21.2 & 15.9 \\
\hline $\mathrm{MgO}$ & 1.59 & 1.68 & 1.31 & 1.36 & & $\mathrm{NE}$ & & 3.6 \\
\hline $\mathrm{CaO}$ & 5.55 & 5.87 & 7.08 & 7.36 & & WO & & 1.3 \\
\hline $\mathrm{Na}_{2} \mathrm{O}$ & 3.16 & 3.34 & 4.97 & & DI & $\mathrm{EN}$ & & 0.4 \\
\hline $\mathrm{K}_{2} \mathrm{O}$ & 3.19 & 3.37 & 3.64 & 3.79 & & FS & & 1.0 \\
\hline $\mathrm{TiO}_{2}$ & 2.85 & 3.01 & 1.52 & 1.58 & & $\mathrm{EN}$ & 3.4 & \\
\hline $\mathrm{P}_{2} \mathrm{O}_{5}$ & 1.15 & 1.22 & 2.57 & 2.67 & HY & FS & 12.3 & \\
\hline $\mathrm{MnO}$ & 0.11 & 0.12 & 0.11 & 0.12 & & FO & 0.6 & 2.1 \\
\hline $\mathrm{H}_{2} \mathrm{O}^{*}$ & 5.41 & & 3.66 & & & FA & 2.3 & 5.4 \\
\hline \multirow[t]{2}{*}{$\mathrm{CO}_{2}$} & 0.09 & & 0.34 & & & MT & 3.0 & 1.6 \\
\hline & & & & & & IL & 5.7 & 3.0 \\
\hline \multirow[t]{3}{*}{ Total } & 100.12 & 100.00 & 100.12 & 100.00 & & AP & 2.9 & 6.3 \\
\hline & & & & & & - & & \\
\hline & \multicolumn{4}{|c|}{ Trace elements (in P.P.M.) } & & SALIC & 69.9 & 79.0 \\
\hline $\mathrm{Cr}$ & 343 & & 6 & & & FEMIC & 30.1 & 21.1 \\
\hline V & 308 & & 132 & & & - & & \\
\hline $\mathrm{Zr}$ & 305 & & 460 & & & D.I. & 48.2 & 63.1 \\
\hline
\end{tabular}

Analyst: K. Ramlal, University of Manitoba.

$\mathrm{A}$-Whole rock major and trace element analyses;

B-Analyses normalized to $100 \%, \mathrm{Fe}_{2} \mathrm{O}_{3} / \mathrm{Fe}^{*}$ adjusted to 0.15 . C.I.P.W. norms for anhydrous analyses on an anhydrous basis.

Table 3. Summary of petrographic modes of analyzed samples. ${ }^{1}$

\begin{tabular}{lcc}
\hline & $59-1$ & $59-7$ \\
\hline Phenocrysts & 5 & \\
Olivine & 1 & \\
Plagioclase & 4 & 1 \\
Clinopyroxene & 2 \\
Amphibole & & \\
Groundmass & & 37 \\
Plagioclase & 27 & 5 \\
Olivine & 19 & 34 \\
Clinopyroxene & 17 & 9 \\
Amphibole & 12 & 12 \\
Opaques & & 10 \\
Altered intersitital & 15 & \\
material & 22 & \\
Vesicularity & & \\
\hline
\end{tabular}

${ }^{1}$ Vesicle-free modes based on 500 points per sample. 
Table 4. Trace, rare-earth element, and chondrite normalized rare earth elements abundances.

\begin{tabular}{|c|c|c|c|c|}
\hline & \multicolumn{2}{|c|}{$59-1$} & \multicolumn{2}{|c|}{$59-7$} \\
\hline & A & B & A & B \\
\hline $\mathrm{Li}$ & 17.3 & & 17.7 & \\
\hline K & 27500 & & 31100 & \\
\hline $\mathrm{Rb}$ & 57.9 & & 97.8 & \\
\hline $\mathrm{Sr}$ & 583 & & 633 & \\
\hline $\mathrm{Ba}$ & 406 & & 1090 & \\
\hline $\mathrm{Ce}$ & - & & 121 & 154 \\
\hline $\mathrm{Nd}$ & 45.3 & 78.0 & 46.1 & 79.4 \\
\hline $\mathrm{Sm}$ & 9.00 & 48.6 & 75.2 & 40.6 \\
\hline $\mathrm{Eu}$ & 2.76 & 38.9 & 2.08 & 29.3 \\
\hline Gd & 10.1 & 39.9 & 6.50 & 25.4 \\
\hline Dy & 8.52 & 28.1 & 5.25 & 17.3 \\
\hline $\mathrm{Er}$ & 4.45 & 24.4 & 2.88 & 15.8 \\
\hline $\mathrm{Yb}$ & 3.75 & 19.9 & 2.82 & 15.0 \\
\hline $\mathrm{Lu}$ & 0.49 & 14.5 & 0.41 & 12.0 \\
\hline
\end{tabular}

Analyst: G. Davis, Hawaii Institute of Geophysics.

A: Trace and rare-earth element abundances (in P.P.M).

B: Chondrite-normalized rare-earth values.

The abundance of total $\mathrm{H}_{2} \mathrm{O}$ and the large proportion of iron as $\mathrm{Fe}_{2} \mathrm{O}_{3}$ reflects the degree of alteration of these basalts. Dredge rock 59-7 appears to be less altered than 59-1 with a lower $\mathrm{Fe}_{2} \mathrm{O}_{3} / \mathrm{FeO}^{*}$ ratio and total $\mathrm{H}_{2} \mathrm{O}$. Perhaps this is a reflection of the lower vesicularity of $59-7(10 \%$ versus $22 \%$ by mode). The geochemical effects of seawater-basalt interaction at low temperatures $\left(>50^{\circ} \mathrm{C}\right)$ have been reviewed by several authors (Philpotts et al., 1969; HART, 1970; Melson, 1973; ThOMPSON, 1973; HART et al., 1974). The effects on whole rock geochemistry of weathering are a general increase in $\mathrm{K}$, Na, $\mathrm{Fe}_{2} \mathrm{O}_{3} / \mathrm{FeO}^{*}, \mathrm{P}, \mathrm{H}_{2} \mathrm{O}$, and $\mathrm{CO}_{2}$, a decrease in $\mathrm{Mg}$, $\mathrm{Ca}$, and $\mathrm{Si}$, variable effects on $\mathrm{Al}, \mathrm{Ti}$, total $\mathrm{Fe}, \mathrm{Ni}$, and $\mathrm{Cr}$, but little effect on $\mathrm{Zr}$ or the rare-earth elements.

Because of the weathering, caution is indicated in the detailed interpretation of the geochemistry of the basalts from Nagata Seamount. However, despite the effects of alteration, the lavas show geochemical affinities in agreement with their alkalic petrography. In Fig. 12, a plot of total alkalis versus silica, both lavas fall well within the alkali field. Figure 13, a plot of the Thornton and Tuttle Differentiation Index versus normative felsic minerals, indicates that both lavas have chemical affinities to hawaiites and mugearites (BAss et al., 1973) and the alkali basalt series lavas of Hawaii (MACDONALD, 1968). Sample 59-7 has higher concentrations of $\mathrm{SiO}_{2}, \mathrm{Al}_{2} \mathrm{O}_{3}, \mathrm{Na}_{2} \mathrm{O}, \mathrm{K}_{2} \mathrm{O}, \mathrm{P}_{2} \mathrm{O}_{5}, \mathrm{Zr}, \mathrm{Ba}$, $\mathrm{Rb}$, and $\mathrm{Sr}$ than does 59-1, whereas sample 59-1 has higher amounts of $\mathrm{Cr}, \mathrm{V}$, and total iron than does sample 59-7. Both basalts have light rare-earth element (LREE) enriched patterns (Fig. 14) typical of most alkali basalts (SUN and HANSON, 1975). However, the absolute abundances of the heavy REE's (HREE) are lower for 59-7, which is the more fractionated rock, than for 59-1. If these two basalt types are derived from related liquids, their geochemical differences can be explained by low pressure fractional crystallization of clinopyroxene and/or amphibole from a LREE-enriched alkalic basalt (DAVIS, 1982). 


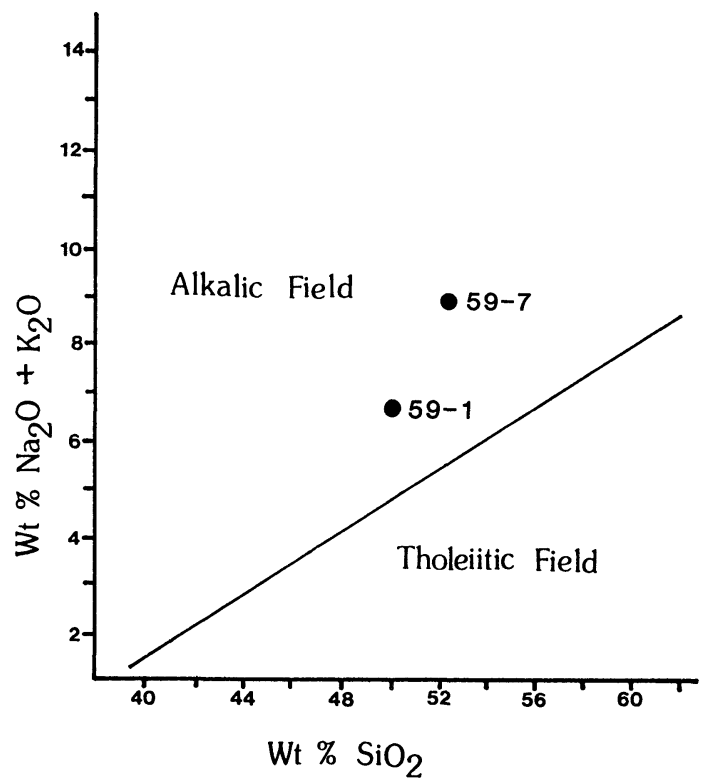

Fig. 12. Plot of total alkalis versus silica for samples 59-7 and 59-1.

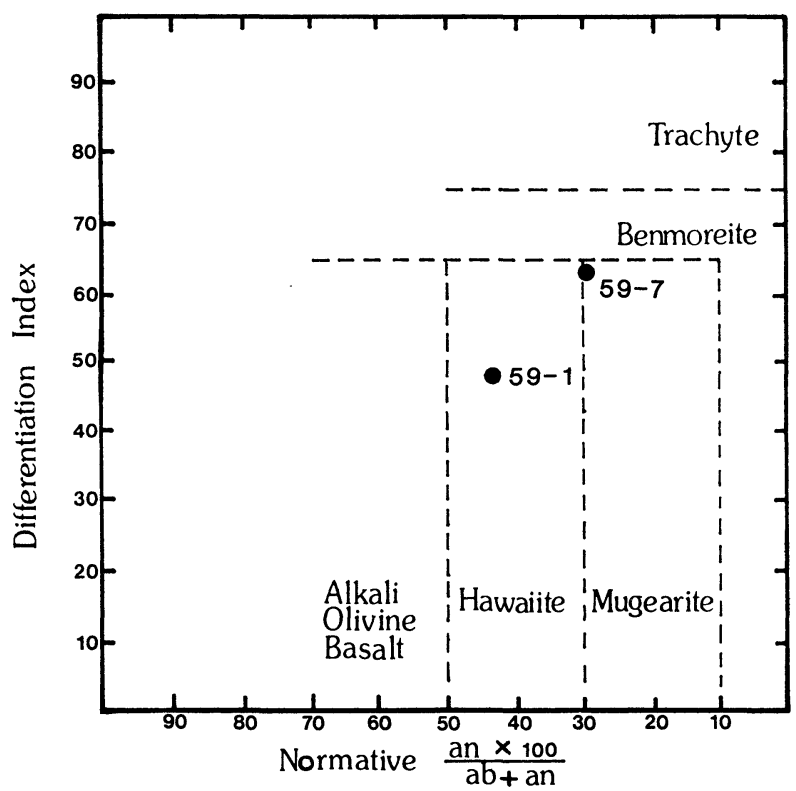

Fig. 13. Plot of Thornton-Tuttle Differentiation Index versus normative felsic minerals for samples 59-7 and 59-1. 


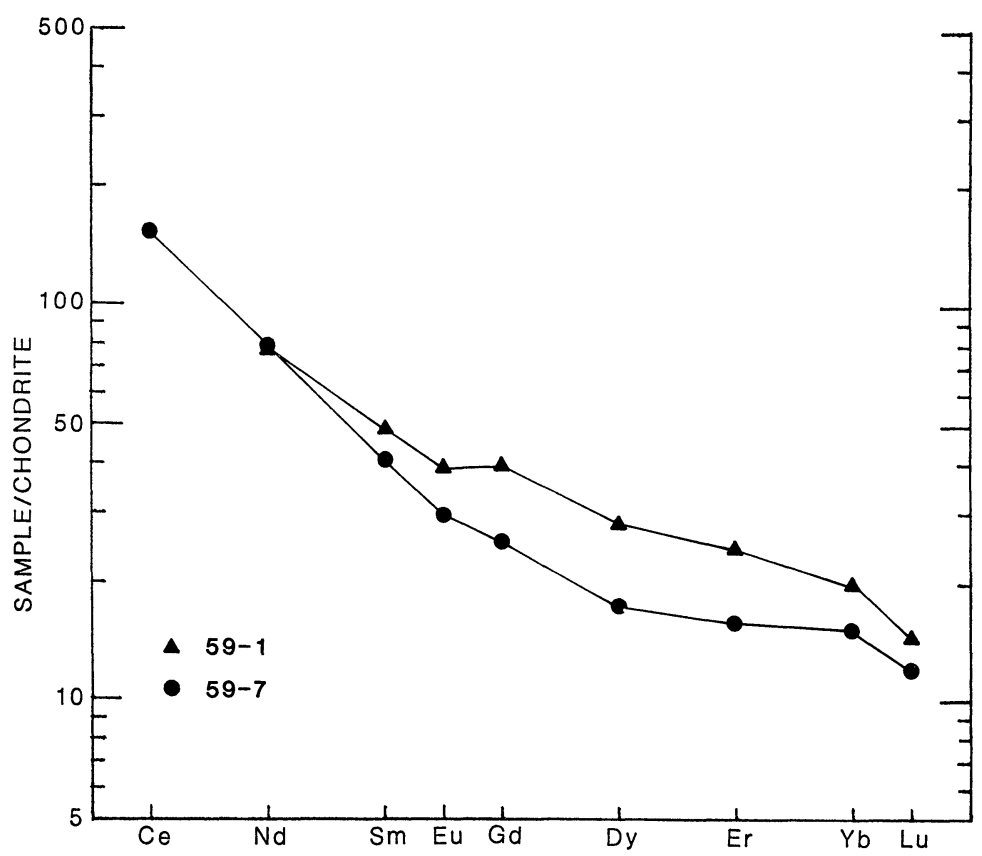

Fig. 14. Chondrite normalized rare earth patterns for samples 59-7 and 59-1.

\subsection{Hyaloclastite breccias}

A portion of dredge RD-059 was composed of rounded to angular cobbles and fragments of volcaniclastic breccias of two varieties. The more abundant variety contains well-sorted, non-stratified clasts of severely altered and oxidized volcanics (less than $1.5 \mathrm{~cm}$ in diameter). These volcanics may represent a high temperature fracturing and rapid hydration of glassy pillow rims and breccia fragments of submarine extruded lavas (BonATTI, 1965). The other variety contains less-altered lithic clasts of $0-10 \%$ vesicular olivine-phyric basalt, some clasts having altered pillow rims. Both breccia types are cemented with microcrystalline siliceous and phosphoritic material and often contain clays within interclast spaces and fractures. Some of the fragments have manganese coats of variable thickness that can appear as thin, patchy crusts or be up to $3 \mathrm{~cm}$ thick.

\section{$6.4 \quad K /$ Ar Ages}

Conventional K/Ar ages for three Nagata Seamount basalts were determined at the University of Hawaii. The whole rock ages and analytical data used in the calculations are presented in Table 5. Sample 59-2 is an alkali olivine basalt similar to 59-1. Sample 59-13 is an amphibole-phyric alkali basalt similar to 59-7. The dual ages reported for 59-2 and 59-7 are ages for rock separates of the same sample chips treated with a weak nitric acid $(\mathrm{N})$ and weak sulfuric acid (S) leach prior to analysis.

The ages for 59-7 and 59-13 cluster around $86 \mathrm{Ma}$. The ages for 59-2 are significantly younger, clustering around $70 \mathrm{Ma}$. Normal basalt-seawater alteration lowers the $\mathrm{K} / \mathrm{Ar}$ age by the gradual loss of $\mathrm{Ar}$ and the influx of $\mathrm{K}$ into smectites during glass mesostasis 
Table 5. K-Ar age determinations.

\begin{tabular}{|c|c|c|c|c|c|c|}
\hline \multicolumn{4}{|c|}{ Sample } & \multicolumn{3}{|c|}{ Radiogenic air } \\
\hline Sample & WT. (g) & $\% \mathrm{~K}$ & $\mathrm{RSD}^{(1)}$ & $\left(\times 10^{-6}\right)$ & $R^{\circ} \%^{(2)}$ & Age $(\mathrm{Ma})^{(3)}$ \\
\hline $59-2 \mathrm{~N}$ & 1.0931 & 2.016 & 0.039 & 5.4398169 & 62.5 & $68.1 \pm 4.1$ \\
\hline $59-2 \mathrm{~S}$ & 1.1654 & 2.189 & 0.055 & 6.1868233 & 62.4 & $71.3 \pm 5.0$ \\
\hline 59-7 N & 1.0867 & 2.984 & 0.008 & 9.5900598 & 80.7 & $80.9 \pm 3.7$ \\
\hline 59-7 S & 1.0637 & 2.778 & 0.027 & 9.8877522 & 71.9 & $89.3 \pm 4.6$ \\
\hline $59-13 \mathrm{~N}$ & 2.2687 & 1.302 & 0.002 & 4.4155 & 83.5 & $86.8 \pm 2.3$ \\
\hline
\end{tabular}

Analyzed in the laboratory of J. J. Naughton, University of Hawaii.

${ }^{(1)}$ Mean and range of two measurements;

${ }^{(2)} R=40 \mathrm{Ar}\left(\mathrm{RAD}_{1}\right) / \mathrm{Ar}(\mathrm{TOTAL}) \times 100$;

${ }^{(3)}$ Errors are estimates of standard deviation of precision.

alteration (OzIMA et al., 1977). These effects are maximized in more vesicular samples, as in 59-2, which permit more seawater circulation. Thus we assume that the ages determined for sample 59-2 are artificially low, and that an average of the ages of 59-7 and 59-13, i.e. 85.6 $\mathrm{Ma}$, is a better indication of the age of the seamount. This age agrees with an $\mathrm{Ar}^{39} / \mathrm{Ar}^{40}$ age of 85 Ma determined from RD-59 samples by R. Duncan (SCHLANGER et al., 1982 see ref.). It is also very close to the $\mathrm{Ar}^{39} / \mathrm{Ar}^{40}$ age of $84 \mathrm{Ma}$ for nearby Kapsitotwa Seamount (SAITo and OzImA, 1977) (see Fig. 1).

\section{Discussion}

\subsection{Basalts and breccias}

The rocks dredged from Nagata Seamount are of two types: alkalic basalts and hyaloclastite breccias. According to BATIZA (1977), seamounts of this size usually form from a tholeiitic core capped by alkalic lavas. The fact that we recovered no tholeiite in our dredge implies that the tholeiites, if present, have been covered by the alkalic material. As we recovered both alkalic basalts and hyaloclastite breccias in the dredge, it may be that both the basalts and breccias occur as outcrops on the seamount flank at the depth at which we dredged. This fact suggests that Nagata Seamount might appear much like those seamounts observed via submersible by LONSDALE and BATIZA (1981). Thus this seamount may be characterized by three major components: a tholeiitic core (which we did not sample), an alkalic mantle that covers most or all of the tholeiite, and a discontinuous veneer of hyaloclastite breccias.

Although the hyaloclastite veneer may be discontinuous at the upper levels of the seamount, about the base it thickens considerably. In Fig. 3 sediment is seen on the lower slopes of the seamount. The reflection records indicate that the sediment is rough and jumbled with no coherent internal reflectors, and it assumes a very low angle of repose about the base of the seamount. Away from the seamount, internal reflectors become more coherent and the sediment takes on the character of the stratified turbidite sequences ubiquitous elsewhere in the Line Islands (OR wIG, 1981). We feel that the sediments seen in Fig. 3 are the same hyaloclastite material that we dredged farther up the seamount. 
According to MCBIRney (1963), hyaloclastite flows resembling underwater nuees ardents should be a common feature of submarine eruptions at shallow to moderate depths. These flows should be very fluid and capable of traveling large distances. Such properties could account for the low angle of repose and the concentration of the hyaloclastite at the base of the seamount. The rough surface and jumbled appearance of the reflections from this material are probably due to slumping of the hyaloclastite during and after deposition.

\subsection{Morphology and history}

From Fig. 2, Nagata Seamount appears to be a simple, conical volcano. Thus it would be reasonable to accord it a simple evolution. There is, however, evidence that the seamount may have been once close to sea level. The most compelling evidence in favor of shallow water volcanism on Nagata Seamount is the high vesicularity (up to $35 \%$ by mode) of some of the dredged basalts. The large amount of hyaloclastite produced by the seamount also suggests moderately shallow eruptions. Two other observations lend credence to this hypothesis. A pelecypod shell fragment was discovered in the cement of one of the breccia samples (J. A. Haggerty, personal communication, 1981). Also, the high degree of oxidation of the breccias implies that Nagata Seamount may have been sub-aerial at some stage. While none of these observations alone constrain the seamount to shallow water, together they are evidence in favor of it.

On the other hand, the shape of Nagata Seamount's summit suggests eruption in deep water. JONES (1966) observed that volcanoes erupting in shallow water tend to have flat tops. However, the summit of Nagata Seamount has steep sides (up to $30^{\circ}$ ) typical of deep water volcanism (JONES, 1966). Concordant with this observation is our failure to dredge any of the coral or reef debris common on seamounts in the central and southern Line Islands.

The simplest hypothesis for the formation of Nagata Seamount is as follows. The volcano began erupting during the Santonian stage of the Late Cretaceous period. Like many other Pacific seamounts (BATIZA, 1977), more or less continuous eruptions, over a period of a few million years at most, built the seamount to near its present height and shape. The reversed magnetic polarity of the summit probably indicates the end of the Cretaceous quiet interval which occurred at $84 \mathrm{Ma}$ according to the time scale of LowRIE and Alvarez (1981). During the later stages of its construction, Nagata Seamount continued to build into water shallow enough to allow its lavas to solidify with a high volume of vesicles, yet deep enough to prevent the eruptions from becoming very explosive and thereby creating flattened top as per JONES (1966). In order for the seamount to have formed entirely underwater, subsidence curves (SCLATER et al., 1971) dictate that the underlying oceanic lithosphere must have been at least 15-20 Ma in age. This inference agrees with the assumed age of the lithosphere beneath the Line Islands (WINTERER, 1976).

\section{Conclusions}

Nagata Seamount formed approximately $84-86$ million years ago. It is composed either entirely or in part by alkali basalts. The lower slopes are covered by a large amount of hyaloclastite debris. Although the bulk of the seamount is normally polarized, the upper $1,000 \mathrm{~m}$ are reversely polarized. Magnetic modeling of the seamount gives a VGP at $61.6^{\circ} \mathrm{N}, 4.0^{\circ} \mathrm{E}$ which is consistent with a Middle Late Cretaceous age for the seamount. The 
average density of the seamount is $2.5 \mathrm{~g} / \mathrm{cm}^{3}$. At some time during its history, Nagata Seamount may have been at sea level or emergent.

We acknowledge the cooperation and assistance of our co-investigators on this project, S. Schlanger, M. Garcia, and J. Naughton. In addition we thank R. Blakely and D. Plouff for assisting with the magnetic and gravity modeling programs and also J. M. Sinton and T. Brocher for helpful comments and discussion and to R. Pujalet for proofreading the manuscript. We also thank the captain, crew, and scientists of the R/V KANA KEOKI without whom this research could not have been done. This work was supported by the Office of Naval Research.

\section{REFERENCES}

Bass, M. N., R. Moberly, Jr., J. M. Rhodes, C. Shin, and S. E. ChurCh, Volcanic rocks cored in the central Pacific, Leg 17, Deep Sea Drilling Project, in Initial Reports of the Deep Sea Drilling Project, Vol. 17, edited by E. L. Winterer, J. I. Ewing et al., pp. 429-503, U.S. Govt. Printing Office, Washington, D.C., 1973.

Batiza, R., Age, volume, compositional and spatial relations of small isolated oceanic central volcanoes, Marine Geology, 24, 169-183, 1977.

Bonatti, E., Palagonite, hyaloclastites, and alteration of volcanic glass in the ocean, Bull. Volcanol., 28, 257-269, 1965.

DAvis, G. T., A petrologic investigation of the Line Islands, central Pacific ocean, M. S. thesis, University of Hawaii, Honolulu, 100 pp., 1982.

Garland, G. D., The Earth's Shape and Gravity, 183 pp., Pergamon Press, New York, 1965.

Gordon, R. G. and A. Cox, Calculating paleomagnetic poles for oceanic plates, Geophys. J. R. Astr. Soc., 63, 619-640, 1980.

Harrison, C. G. A., A seamount with a nonmagnetic top, Geophysics, 36, 349-357, 1971.

Harrison, C. G. A., R. D. JARrard, V. VACQUiER, and R. L. LARson, Paleomagnetism of Cretaceous Pacific seamounts, Geophys. J. R. Astr. Soc., 42, 859-882, 1975.

HARRISON, J. C. and W. C. BrisBin, Gravity anomalies off the west coast of North America, 1 : Seamount Jaspar, Bull. Geol. Soc. Am., 70, 929-934, 1959.

HART, S. R., Chemical exchange between seawater and deep ocean basalts, Earth Planet. Sci. Lett., 9, 269-279, 1970.

HART, S. R., A. J. ErLANK, and E. J. D. KABLE, Seafloor basalt alteration : some chemical and Sr isotopic effects, Contrib. Mineral. Petrol., 44, 219-230, 1974.

Heiskanen, W. A. and H. Moritz, Physical Geodesy, 364 pp., W. H. Freeman Co., San Francisco, 1967.

JONES, J. G., Intraglacial volcanoes of southwest Iceland and their significance in the interpretation of the form of the marine basaltic volcanoes, Nature, 212, 586-588, 1966.

Keating, B. and W. SAGER, Watkins seamount: preliminary paleomagnetic results, J. Geophys. Res., 85, 3567-3571, 1980.

LAMBERT, I.B. and P. J. WYLLIE, Low-velocity zone of the earth's mantle: incipient melting caused by water, Science, 169, 764-766, 1970.

LePichon, X. and M. TALwANI, Gravity survey of a seamount near $35^{\circ} \mathrm{N} 46^{\circ} \mathrm{W}$ in the north Atlantic, Marine Geology, 2, 262-277, 1964.

LINES, L. R. and F. N. Jones, The perturbation of alternating geomagnetic fields by three dimensional island structures, Geophys. J. R. Astr. Soc., 32, 133-154, 1973.

LONSDAlE, P. and R. BATIZA, Hyaloclastite and lava flows on young seamounts examined with a submersible, Bull. Geol. Soc. Am., part I, 91, 545-554, 1981.

Lowrie, N. and W. Alvarez, One hundred million years of geomagnetic polarity history, Geology, 9, 392-397, 1981 .

Macdonald, G. A., Composition and origin of Hawaiian lavas, in Studies in Volcanology, edited by R. R. Coats, R. L. Hay, and C. A. Anderson, Geol. Soc. Am. Mem., 116, pp. 477-522, Geol. Soc. Am., Boulder, Co., 1968.

Macdonald, G. A. and T. Katsura, Chemical composition of Hawaiian lavas, J. Petrol., 5, 82-133, 1964.

Matthews, D. J., Tables of the Velocity of Sound in Pure Water and Sea Water for Use in Echo-Sounding and Sound Ranging, 2nd ed., H. D. 282, 52 pp., Admiralty Hydrogr. Dep., London, 1939. 
McBirney, A., Factors governing the nature of submarine volcanism, Bull. Volcanol., 26, 455-469, 1963.

Melson, W. G., Basaltic glasses from the DSDP : chemical characteristics, compositions of alteration products, and fission-track ages, Trans. Am. Geophys. Union, EOS, 54, 1011-1014, 1973.

NaGata, T., Rock Magnetism, 225 pp., Maruzen, Tokyo, 1953.

NAYUDU, Y.R., A new hypothesis for the origin of guyots and seamount terraces, in The Crust of the Pacific Basin, Geophys. Mon. Ser., Vol. 6, edited by G. A. Macdonald and H. Kuno, pp. 171-180, AGU, Washington, D.C., 1962.

ONwUmeChilli, A., Geomagnetic variations in the equatorial zone, in Physics of Geomagnetic Phenomena, Vol. I, edited by S. Matsushita and W. H. Campbell, pp. 425-507, Academic Press, New York, 1967.

ORwiG, T. L., Channeled turbidites in the eastern central Pacific basin, Marine Geology, 39, 33-57, 1981.

Ozima, M., M. Honda, and K. SaIto, ${ }^{40} \mathrm{Ar}-{ }^{39} \mathrm{Ar}$ ages of guyots in the western Pacific and discussion of their evolution, Geophys. J. R. Astr. Soc., 51, 475-485, 1977.

Philpotts, J. A., C. C. Schnetzler, and S. R. HART, Submarine basalts: some K, Rb, Sr, Ba, rare-earth, $\mathrm{H}_{2} \mathrm{O}$, and $\mathrm{CO}_{2}$ data bearing on their alteration, modification by plagioclase, and possible source materials, Earth Planet. Sci. Lett., 7, 293-299, 1969.

Plouff, D., Gravity and magnetic fields of polygonal prisms and application to magnetic terrain corrections, Geophysics, 41, 727-741, 1976.

Richards, M. L., V. VACQUiER, and G. D. VAN VoORHIS, Calculation of the magnetization of uplifts from combining topographic and magnetic surveys, Geophysics, 32, 678-707, 1967.

Robertson, E. I., Gravity effects of volcanic islands, New Zealand, J. Geol. Geophys., 10, 1466-1483, 1967.

RoberTSON, E. I., Additional gravity surveys in the Cook Islands, New Zealand, J. Geol. Geophys., 13, 184-198, 1970.

SaIto, K. and M. OzIma, ${ }^{40} \mathrm{Ar}^{39} \mathrm{Ar}$ geochronological studies on submarine rocks from the western Pacific area, Earth Planet. Sci. Lett., 33, 353-369, 1977.

Schimke, G. R. and C. G. Bufe, Geophysical description of a Pacific ocean seamount, J. Geophys. Res., 73, $559-569,1968$.

Schlanger, S. O., M. O. Garcia, J. Haggerty, B. Keating, J. J. Naughton, J. A. Philpotts, W. Sager, and R. DunCAN, Geologie evolution of the Line Islands (abstract), The Origin and Evolution of Seamounts Conference, Lamont-Doherty Geological Observatory, Palisades, N. J., Nov. 17-18, 1982.

SClATER, J. G., R. N. ANDERSON, and M. L. Bell, Elevation of ridges and evolution of the central eastern Pacific, J. Geophys. Res., 767, 7888-7915, 1971.

Strange, W. E., G. P. Woollard, and J. C. Rose, An analysis of the gravity field over the Hawaiian Islands in terms of crustal structure, Pac. Sci., 19, 381-389, 1965.

Sun, S. S. and G. N. Hanson, Evolution of the mantle: geochemical evidence from alkali basalt, Geology, 3, 297-302, 1975.

THOMPSON, G., A geochemical study of the low temperature interaction of seawater and oceanic igneous rocks, Trans. Am. Geophys. Union, EOS, 54, 1015-1019, 1973.

VACQUIER, V., A machine method for computing the magnetization of a uniformly magnetized body from its shape and a magnetic survey, in Proc. Benedum Earth Magnetism Symposium, Pittsburgh, pp. 123-137, 1962.

Winterer, E. L., Anomalies in the tectonic evolution of the Pacific, in The Geophysics of the Pacific Ocean Basin and its Margin, Geophys. Mon. Ser., Vol. 19, edited by G. H. Sutton, M. H. Manghnani, and R. Moberly, pp. 269-278, AGU, Washington, D.C., 1976.

WoOllard, G.P., A gravity reconnaissance of the island of Oahu, Trans. Am. Geophys. Union, EOS, 32, 358-368, 1951.

Woollard, G. P. and J. C. Rose, International Gravity Measurements, 518 pp., Society of Exp. Geophys., Tulsa, Okla, 1963. 